\title{
Introduction: Mediated Cultural Encounters in Europe
}

Bondebjerg, Ib; Redvall, Eva Novrup

Published in:

European Cinema and Television

Publication date:

2015

Document version

Publisher's PDF, also known as Version of record

Citation for published version (APA):

Bondebjerg, I., \& Redvall, E. N. (2015). Introduction: Mediated Cultural Encounters in Europe. In I. Bondebjerg,

E. N. Redvall, \& A. Higson (Eds.), European Cinema and Television: Cultural Policy and Everyday Life (pp. 1-

22). Palgrave Macmillan. Palgrave European film and media studies 


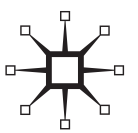

Selection and editorial matter (C) Ib Bondebjerg, Eva Novrup Redvall and Andrew Higson 2015

Individual chapters (C) Respective authors 2015

All rights reserved. No reproduction, copy or transmission of this publication may be made without written permission.

No portion of this publication may be reproduced, copied or transmitted save with written permission or in accordance with the provisions of the Copyright, Designs and Patents Act 1988, or under the terms of any licence permitting limited copying issued by the Copyright Licensing Agency, Saffron House, 6-10 Kirby Street, London EC1N 8TS.

Any person who does any unauthorized act in relation to this publication may be liable to criminal prosecution and civil claims for damages.

The authors have asserted their rights to be identified as the authors of this work in accordance with the Copyright, Designs and Patents Act 1988.

First published 2015 by

PALGRAVE MACMILLAN

Palgrave Macmillan in the UK is an imprint of Macmillan Publishers Limited, registered in England, company number 785998, of Houndmills, Basingstoke, Hampshire RG21 6XS.

Palgrave Macmillan in the US is a division of St Martin's Press LLC, 175 Fifth Avenue, New York, NY 10010.

Palgrave Macmillan is the global academic imprint of the above companies and has companies and representatives throughout the world.

Palgrave ${ }^{\circledR}$ and Macmillan ${ }^{\circledR}$ are registered trademarks in the United States, the United Kingdom, Europe and other countries.

ISBN 978-1-137-35687-1

This book is printed on paper suitable for recycling and made from fully managed and sustained forest sources. Logging, pulping and manufacturing processes are expected to conform to the environmental regulations of the country of origin.

A catalogue record for this book is available from the British Library.

Library of Congress Cataloging-in-Publication Data

European cinema and television: cultural policy and everyday life / [edited by] Ib Bondebjerg, University of Copenhagen, Denmark ; Eva Novrup Redvall, University of Copenhagen, Denmark; Andrew Higson, University of York, UK. pages $\mathrm{cm}$-(Palgrave European film and media studies)

Includes bibliographical references and index.

ISBN 978-1-137-35687-1

1. Motion pictures-Europe-History and criticism. 2. Motion picturesSocial aspects-Europe. 3. Identity (Psychology) in motion pictures.

4. Television programs-Europe. 5. Television programs-Social aspectsEurope. 6. Identity (Psychology) on television. I. Bondebjerg, Ib, editor.

II. Redvall, Eva Novrup. III. Higson, Andrew.

PN1993.5.E8E968 2015

$791.43094-d c 23$

2015003224

Typeset by MPS Limited, Chennai, India.

Copyrighted material - 978-1-137-35687-1 


\section{Contents}

List of Figures and Tables

vii

Notes on Contributors

Introduction: Mediated Cultural Encounters in Europe

Ib Bondebjerg and Eva Novrup Redvall

Part I Culture, Identity and Everyday Life

1 Narratives of European Identity Monica Sassatelli

2 Film and European Identity: A German Case Study Michael Meyen

3 Sensing National Spaces: Representing the Mundane in English Film and Television

Tim Edensor

Part II Film and Media Policy: Between the National and the Transnational

4 The European Audiovisual Space: How European

Media Policy Has Set the Pace of Its Development

Carmina Crusafon

5 Beyond Borders and into the Digital Era: Future-proofing European-level Film Support Schemes

Sophie De Vinck and Caroline Pauwels

\section{Part III National Cinemas - European Cinemas}

6 British Cinema, Europe and the Global Reach for Audiences

Andrew Higson

7 The East Meets the West in Contemporary Eastern European Films

Ewa Mazierska

8 New Voices, New Stories: Migrant Cinema and Television in Norway

Leif Ove Larsen 
vi Contents

\section{Part IV National Television - European Television}

9 Italian TV Drama: The Multiple Forms of European Influence

Milly Buonanno

10 Breaking Borders: The International Success of Danish Television Drama

Ib Bondebjerg and Eva Novrup Redvall

11 Small Nation/Big Neighbours: Co-producing Stories in a European Context

Diog O'Connell

Index 


\title{
Introduction: Mediated Cultural Encounters in Europe
}

\author{
Ib Bondebjerg and Eva Novrup Redvall
}

Research on film and television in Europe tends to adopt a nation state framework, despite the fundamental changes brought about by increased globalization and collaboration as well as transnational cultural policy on a European level since the 1990s. Furthermore very little research on European film and television takes a broader social and cultural look at the role of film and television in the forming of our everyday life and in the creation of transnational images of Europe and the construction of cultural identities. In this volume we focus on European film and television culture with the purpose of analysing how important media have become for the cultural integration and development of a Europe beyond the nation state. The ongoing globalization is not just about the strong presence of US film and television in Europe - a long-established fact of modern media culture. It is also about the role European film and television already plays in the everyday life and media culture of Europeans, and the political and cultural challenges Europe faces with increased globalization and digitization.

Cultural encounters mediated through film and television matter. We broaden our experience of the cultural diversity of Europe through the experiencing of film and television from different parts of Europe. The power of European stories, like stories from other parts of the world, is such that they increase our ability to begin to imagine a broader European community. Although this has been a vital part of and reason for EU film and television policy for decades, the results have still not been very impressive. The rich, cultural diversity of Europe also means a very nationally fragmented Europe, it means the lack of a strong production and distribution network covering Europe. 


\section{Ib Bondebjerg and Eva Novrup Redvall}

\section{Studying European culture: new perspectives}

This book offers comparative studies of the production, distribution content and reception of film and TV drama in Europe. The chapters focus on the role that film and TV drama plays in the everyday lives of European citizens, the role that audiovisual fiction plays in the process of establishing and maintaining a sense of European identity and the extent to which new developments in terms of film and TV drama production, distribution and reception are shaped by national and EU policies and practices. The book offers case studies of different forms of transnational collaboration in the production of European films and TV drama and analyses of how cultural products circulate across national borders. Some European film and television formats travel, whereas quite a lot of others do not. We investigate examples of the transnational dialogue between audiences and successful European film and television drama and the way in which such cultural forms can facilitate both a sense of the national differences within Europe and a sense of being a European.

Apart from demonstrating the necessity of a comparative, transnational approach to the study of film and television in Europe, this book also demonstrates the necessity of an interdisciplinary approach. The authors represent humanities scholars who analyse film and television as a form of cultural expression and symbolic form, and social scientists focusing on the sociology of media and the anthropology of everyday life. In the extensive research on film and media in Europe, film and media scholars too often neglect to link the study of media content and genres to a broader study of audiences and reception, whereas scholars from social and political science tend to overlook the role of film and television content in the forming of our values, ideas and ways of living. This book insists on the value of including both perspectives and on the need to combine quantitative and qualitative studies of the main trends in transnational European film and television and the role these media play in the lives of ordinary Europeans while demonstrating this comparative and interdisciplinary approach in practice.

\section{Screening Europe: unity in diversity}

This book focuses on Europe, a Europe that is more than the European Union. The forming of the EEC (and subsequent EU) in 1957 came after a war that had torn Europe apart and still left open scars and divisions between East and West, but the walls established in the Cold War period are not the only walls in European history. The history of Europe is one 
of shifting nation state borders, shifting coalitions and collaborations between friends or former enemies, and it is the history of wars between nation states and regional powers. The ancient and classical history of Europe is a story of shifting empires and wars between nation states wanting to expand. However, the experiences of World War II brought Europe closer together. The founding treaty of modern Europe, the Treaty of Rome (1957) is primarily a pragmatic treaty of a social and economic nature, describing a union 'determined to lay the foundations of an ever closer union among the peoples of Europe' and 'resolved to ensure the economic and social progress of their countries by common action to eliminate the barriers which divide Europe' (Treaty of Rome 1957). But beneath this pragmatic union was a wider political and cultural dream of Europe, a Europe developing communication networks between different people and nation states, and supporting the 'flowering of cultures of the Member States' (Treaty of Rome 1957).

From the beginning, there was a vision of a European union where people were both nationals and Europeans, without a conflict between those two identities. Part of this vision was having the role of culture and communication at the core of the European project. Although this was originally not so highlighted and prioritized as the other areas of European collaboration, culture was there from the very start. The independent organization, Council of Europe (henceforth COE), which was founded already in 1949 and in 1950 adopted the European Convention of Human Rights, was an important and very active European organization in the areas of communication and culture. Even before the creation of the European Union, the COE also adopted the European Cultural Convention (1954), which states that its aim is to 'achieve greater unity between its members' and safeguard and realize 'the ideals and principles which are their common heritage' (Council of Europe 1954: 2). Likewise the convention points to promoting 'the study of languages, history and civilization of the others and of the civilization which is common to them' (Council of Europe 1954: 2). The convention also addresses issues such as 'promoting cultural activities of European interest' (Council of Europe 1954: 2) and of facilitating 'the movement of persons as well of objects of cultural value' (Council of Europe 1954: 3).

What we see in these founding texts of European culture and cultural policy are clearly early versions of what later became a guiding principle for the film and media policy, that is the notion of 'unity in diversity', which was adopted as the official motto of the EU in 2000. Unity first of all points to the attempt to create a framework for a common European 


\section{$4 \quad$ Ib Bondebjerg and Eva Novrup Redvall}

cultural space, a space for co-production, collaboration, distribution and exchange of ideas and products, but it also refers to what European nationals can agree upon as a common, historical heritage. Diversity, on the other hand, points to a plurality of nations, regions, languages and traditions, which are seen as the creative richness of Europe as a whole, but it also refers to the need to secure diversity of culture and cultural production, to prevent a commercial homogenization. While conventions are important for creating shared mission statements, words alone do not make European collaboration and integration happen, humans do. The European Broadcasting Union (EBU), the organization of European public service broadcasters, was formed almost the same year as the EC cultural convention, a fact that shows how important media was considered to be at a very early stage in these institutionalized European collaborations. From the start, EBU has secured not just an increasing transmission of European events, creating a sort of European, visual public sphere in politics, culture, sports and entertainment, but also an increasing co-production and co-distribution of national media products to the rest of Europe.

The thoughts, ideas and initiatives from the 1950s did not immediately lead to an expansive and offensive cultural policy in the EU. On the contrary, nation states were keen to protect their national, cultural space, but there were important new developments for film and media policy in the 1980s when the European Commission adopted the Television Without Frontiers document (1984 and 1989) and the MEDIA programme (1987, from 2014 called Creative Europe), while the COE established Eurimages (1988), the first real financial support programme for European film. Even though both programmes have a limited scope compared to the total of national support for film and television in Europe and the money used in the EU on other areas - and even though the economy behind the programmes is not strong enough if Europe is to challenge American dominance of the media market - they send an important signal of European cultural cooperation. With the official treaty article on culture in the Maastricht Treaty from 1992, EU policies have focused increasingly on the cultural dimension and on the strategies to combine unity and diversity. In 1998 a more ambitious strategy became visible as illustrated by this quote from the official EU publication Audiovisual Policy of the European Union: 'the new audiovisual products (...) offer a major opportunity for making the most of Europe's unique treasure - its cultural and linguistic diversity. Audiovisual images attract us as they can simultaneously be a window on the world and a mirror of our own lifestyles and concerns' (European Commission 1998: 6). 
The strategy adopted here has since then been developed into a variety of cultural programmes and initiatives, sometimes described as part of a 'Creative Europe' strategy as stated in the April 2010 Green Paper on cultural and creative industries (European Commission 2010) and supported by the European Forum on Cultural Industries also of that year (http://www.eu2010feic.org/).

The move towards a greater European engagement in developing the European cultural sector is a continuation and strengthening of the strategies behind the already existing cultural policies for film and television and other cultural sectors. Seen from a market perspective the idea is to make it easier for creative industries to work on the European market as a whole, but at the same time there is a clear interest in thinking the European diversity into the adopted strategies. As Monica Sassatelli has argued in her book Becoming Europeans (2009) and elaborates in this anthology, the 'cultural city' concept is a good example of this. Even though the EU is often viewed in popular media, and perhaps also among ordinary Europeans, as a top-down bureaucracy, the cultural city concept is a framework with certain common elements, but completely created from below by the cities chosen. The basic thought behind the new cultural policy of the EU is of course still European, cultural integration and creating a stronger European economy and market that can compete in the global cultural sphere. But there is also a much stronger understanding of the importance of bringing culture actively out to the citizens of Europe, to make it part of the everyday life of Europeans. The diversity of European culture is only a visible reality if we as Europeans are confronted with it on a regular basis. It is not enough to point to the fact that seen from the outside the diversity of a Europe in East and West, North and South is very charming, if this cultural diversity is not activated and distributed to all Europeans.

\section{European culture and everyday life}

As Europeans we have to face the fact that America is a very big part of European culture: jeans, fast food, Coca-Cola, rock ' $n$ ' roll, Disney and Hollywood - to mention just a few cultural symbols and icons are as much a part of the everyday life of every European as pasta, feta cheese, opera or ancient ruins and temples. Most Europeans would have a much easier time identifying five American movies or television series, than naming equivalent European products outside their own national culture. Empirical data going back to 1950 clearly indicate that American films completely dominate the European market. In 2011, the 


\section{Ib Bondebjerg and Eva Novrup Redvall}

figure was almost $64 \%$, based on cinema admissions, and the so-called non-national European share of films (the share of all European films outside their own national territory) was only 8\% (Bondebjerg and Redvall 2011: 14f). The Americans have a clear advantage given the fact that the US functions as one market, whereas Europe is a loose network of more than 30 nation states. American budgets and distribution strategies can work more efficiently on the home market and based on that also globally. As Toby Miller has pointed out in the book Global Hollywood 2, Hollywood seems able to penetrate the home, mind and life of the whole world, and 'we are all experts at understanding Hollywood movies' (2005: 1f). But how much of this is based on production and distribution power and how much has to do with the stories Hollywood studios are so good at telling?

Who are the Europeans? How do we see ourselves? What constitutes a European culture and identity, if such a thing exists? Those are some of the questions we raise in this book, but answers are not easy and simple to provide. In Neil Fligstein's book Euroclash: The EU, European Identity and the Future of Europe (2008) questions like these are dealt with from the perspective of collective identity and national identity. Answers are given based on empirical data derived from European survey responses. Fligstein also analyses the effects of cultural and political institution building for the existence of the rudimentary forms of a common European cultural sphere. Theories of national cultures and national identity often talk about on the one hand a sense of an 'imagined community' (Anderson 1983/1991) which may or may not reflect the 'actual community' residing in a place or located in time. The term imagined community refers to the building and construction of a feeling of a collective identity based on a shared cultural experience through, for instance, literature, media and a common history. However, this feeling of a national culture and identity comes in many forms and it is not always a very strong, coherent or expressive ideology. An imagined community at a national level can cover up cultural and social differences within the nation state, and this of course is even more the case if we try to imagine a European community. When the British sociologist Michael Billig coined the term 'banal nationalism' (Billig 1995), he pointed to the fact that a collective identity in a specific national space can be imbedded in everyday life practices that we may not even notice. Collective identities are furthermore not always very homogenous, or we may have competing or parallel identities, as Fligstein points out (2008: 127f). People grow up in communities formed or influenced by family, work, gender, education, cultural 
preferences etc., and we can have multiple identities, some of which may even seem to conflict. Imagined communities and collective identities can therefore at some levels be very strong, but at other levels they compete with conflicting interest. Our everyday life is in fact a mixture of many layers and practices.

The social and cultural integration of the European nation states have only been under construction since the 1950s, whereas some of the European nation states were formed through a process of hundreds of years. The forming of collective imagined communities takes time, and many factors of a social and cultural nature contribute to such a project. In modern day Europe the mediated forms of cultural encounters play an increasingly strong role. Film and television on many platforms and the new digital media culture are developing more and more transnational patterns of production and distribution. Even though national territories and feelings of national identity still seem to have a very prominent place in the life of Europeans, processes of globalization are pushing the role of nation states in new directions. While globalization may influence from without, many nation states are also under pressure as internal groups seeking national independence or greater selfdetermination gain strength and push from within, as recent events in the UK or Spain - and before that the Balkans - show.

The EU is only 50 years old and the results of the political, social, economic and cultural processes of integration cannot be compared to that of a nation state. Processes of Europeanization are in fact taking place on many levels, and the interaction between citizens and politicians in the greater European space has been expanded considerably. Political decisions affecting all Europeans currently concerns around $80 \%$ of all national legislation and the economic integration is considerable, but not many Europeans are aware of this deep influence of EU on their everyday life. In terms of everyday practices, media use, cultural consumption and personal interactions the picture is much more blurred, and few Europeans would state a European identity as their primary identity. In their book European Media, Stylianos Papathanassopoulos and Ralph Negrine talk about a European identity on three levels: general identity, civic identity and cultural identity (2011: 159). A general European identity can be identified when people clearly and naturally think of themselves as European; a civic identity has to do with whether people identify with the EU institutions; and finally a European cultural identity would mean identifying with some sort of common cultural heritage and a feeling of a cultural identity, not necessarily as strong or stronger than a national identity, but distinct from a non-European identity. 


\section{Ib Bondebjerg and Eva Novrup Redvall}

These three forms of European identity are the basis of a questionnaire they used when analysing how the media in France, UK and Greece responded to the case of Turkey's negotiations to enter EU. The interesting thing here is that the economic reasons for either accepting or rejecting Turkey were not high on the agenda. Instead, questions related to cultural identity in general or cultural identity in particular played a major role. In other words, with different accents a European press and its readers responded negatively to this issue by using a cultural argument (history, culture, memory), but differences in the definitions of this cultural identity also followed ideological lines, where the centreleft position clearly had a more open cosmopolitan discourse than centre-right positions.

This case indicates that defining what is European culture and identity plays an important role already in the way we interact with each other and in the politics and media in Europe. However, this is not necessarily something that is directly reflected in our everyday life discourses, since Europe in this context is substituted with the national. Related to this, the Eurobarometer data have interesting figures on the development of our feeling of being Europeans and of belonging to a European community. In 2004, the data, as reported in Fligstein (2008: 141) were as follows: when people all over Europe were asked whether they thought about themselves as nationals and/or Europeans, 87.3\% said they were mostly national, $12.7 \%$ mostly European and 56\% felt sometimes European. When asked to place nationality and a European identity in connection with each other, $43 \%$ did in fact consider themselves to be both nationals and Europeans, while 44\% considered themselves only nationals. The highest percentage of a national-only identity is perhaps not surprisingly in the UK $(64.7 \%)$, and the lowest in southern Europe (France 30.5\%, Italy 29.3\% and Luxembourg $27.8 \%$ ). The figures here indicate a certain feeling of being European, as a secondary identity, and the different national figures clearly show a difference between the most EU-sceptic countries and those with the most positive attitude to EU.

\section{Dynamics of cultural encounters and media in Europe}

When 56\% of people living in a European nation answer that they feel European 'sometimes', it is interesting to try to understand what might facilitate or trigger this feeling, whether on special occasions or maybe as a more permanent dimension of their identity, next to a primary or other forms of identity. Is it when they watch Eurosport 
or attend Champions League matches (where we do know that people have actually started to be fans of non-national clubs, in many cases probably because of discontent with the national option)? Is it when they watch and vote in the Eurovision Song Contest and feel that they support their national culture but also take part in a common European event? Is it when they vote for the European parliament, even though they can only vote for national candidates? Or is it related to situations where European culture as a whole seems challenged by social and political issues? It is most likely a combination of situations like these plus many other aspects, some of which might also relate to traveling, whether purely for pleasure or through established schemes such as the rather successful Erasmus exchange programmes for students.

Film and media most certainly also play a role here, even with the problem that Europeans do not meet other European nations' film and media products nearly as often in their everyday contexts as they meet their own national cultural products and American products. Both on the national cinema screens and on the television screens in most European homes, American and national products seem to be the most popular. We have no reason to believe that this will change in the near future through the new digital platforms, gradually giving viewers individual choice and control. In one of the biggest European surveys ever made on film preferences and film consumption in Europe (European Commission 2014a and 2014b) the audience is described through different group profiles, and for two of those groups, 'hyperconnected movie addicts' (24\%) and 'rushed independent movie selective' $(22 \%)$, there seems to be a strong interest in a diversity of films, including European. This also goes for smaller groups which the survey identifies as 'Europhiles' and 'film-literates', where there is an even stronger tendency to go for European films understood as different from the national and American mainstream. When people respond to the quality of European films, the respondents use words like 'originality', 'creativity', 'innovation', 'diversity' and 'quality of content' but they also point to barriers like language issues, boring stories and the lack of availability, attention and promotion given to European films (European Commission 2014a: 9-10). So the audience for and interest in European films are there, but the films themselves do not reach this potential audience, and European films end up being given less attention and achieving less awareness compared to home nation and American films.

On a European level, mediated encounters through film and television do not take place to the degree they could, given the fact the total European production of both film and TV drama is much higher than 
the total US production. But where US products effectively reach the whole European market, European products have a fragmented distribution pattern. This fragmented structure of the film and media culture in Europe corresponds to the complicated structure of who Europeans think they are, represented in Fligstein's analysis of the multiple identities in Europe where very few identify themselves as Europeans only (3.9\%) and few put the European identity first and the national second (8.8\%) (Fligstein 2008: 141). Those figures are hardly surprising, neither is the fact that there is a clear differentiation in how one sees oneself based on demographic variations. Professionals and people with a higher education have a much more transnational identity and outlook than other social groups - social interaction is just as efficient for developing a mixed and transnational identity as mediated cultural encounters are. The more you know of and interact with transnational others, the more you develop a transnational identity next to your primary identity. Nationals are different, and so are Europeans of course, but Fligstein's analysis also shows us that we should not forget the relatively short duration of the European project: if interaction and collaboration, if getting together in many ways and communicating across national boundaries is the key dynamic behind European integration, then these dynamic processes are simply not yet sufficiently developed.

The dynamic forces behind Europeanization or European integration have intensified over the last couple of decades, from a merely economic and political cooperation to a broader cultural, but it will take much more than 60 years to match the forces that created the modern nation states several hundreds of years ago. Despite the difficulties, many things have changed in the European project over the years. Within the EU any citizen in one of its nation states lives in a much more European and global environment than 50 years ago. Not only has the European and global economy made us more dependent on each other. Wider political issues have also created a need for more national as well as international responses, and there is a highly increased cultural mobility and connectivity created through a new and more global media culture. This cultural mobility and connectivity still takes place within a communicative framework and a cultural policy largely determined by the nation states. However, the European and global dimension has both an intrinsic and an extrinsic dimension. The intrinsic dimension has to do with forms of multiculturalism in Europe following partly new migration patterns; the extrinsic dimension has to do with both the rise of co-production and transnational collaboration and with the fact that audiences can access a much more broad, global diet of information and cultural products 
via the digital networks. Culture is now also moving online, and even though the online universe also has national boundaries, it is potentially more transnational in both content and usage.

As discussed in Sophie De Vinck and Caroline Pauwels' chapter in this book, the new digital developments should not be seen as a complete change of the already existing media policy and culture in Europe. The traditional forms of flow television and cinema still have a central place in European cinema and television culture, but new forms of online consumption are definitely on the rise. The fact that users have access to a more free choice of content and ways of watching audiovisual products will most certainly influence the way the existing system works. If the traditional and new media together are increasing the forms of mediated encounters in Europe, within Europe - and between Europe and other places in the world - these certainly influence our potential feeling of being not just national, but European and maybe even cosmopolitan. As Europeans we are no doubt still rooted in an everyday culture defined by a certain national and local space, as Tim Edensor points out in his chapter on the mundane dimensions of Britishness. However, the cultural consequences of Europeanization and globalization have been pointed out in many recent works on cultural globalization.

As an example, Arjun Appadurai's book Modernity at Large: The Cultural Dimensions of Globalization (1996) argues that globalization does not necessarily mean homogenization - as others have argued, mainly referring to the global American dominance of culture and our minds (e.g. Herman and McChesney 1997). Media, film and television do matter, and fictional stories are extremely efficient forms of cultural transmission. However, as Appadurai points out, products are actively used by audiences around the world, they are not just passively taken at face value. They present social and cultural forms of imagination that can act as 'scripts for possible lives' (1996: 3), lives that may be different from the screen images, but exactly by being different they might spur a dialogue. So rather than seeing transnational, cultural communication as only a question of dominance, it is important to see it as a potential transformative moment, a moment of a localized, everyday subject within a particular social and cultural framework meeting 'the other'. Appadurai stresses how more people today anticipate changing the way in which they live as well as the place they live in. Modern media cultures in fact work as imaginative links between the existing everyday home culture and other cultural worlds. The media perform a kind of imaginative work by presenting stories of lives, those of ourselves and those of others, that enter into our national, local spaces. 


\section{Ib Bondebjerg and Eva Novrup Redvall}

For an anthropological media researcher like Appadurai, the modern and gradually still more globalized public media sphere is like a developing diasporic community. We may not relate to that community in the same way, and parts of the community are certainly more appealing to some than others. But, as he states, 'the transformation of everyday subjectivities through electronic mediation and the work of the imagination is not only a cultural fact. It is deeply connected to politics, through the new ways in which individual attachments, interests, and aspirations increasingly crosscut those of the nation-state' (Appadurai 1996: 10). As already indicated above, this increase in mediated encounters that crosscut nation state cultures is not very strong when we talk about a European public sphere, at least not in the sense of the interactivity between film and television across nation states in Europe. When it comes to film and television it would certainly be wrong to say that we do not have some sort of common cultural heritage, but as Europeans we take in much more from America than from our own neighbours. As discussed by Milly Buonnano in her chapter on Italian TV drama in this book, there are some patterns of more intense exchange and collaboration based on transnational, regional cultures, such as what she terms a 'privileged Mediterranean connection' based on the closer cultural proximity between Latin European countries that facilitates the exchange of programmes and formats. In their chapter, Ib Bondebjerg and Eva N. Redvall address the long-standing Nordic tradition for collaboration and programme exchange prior to the recent international interest in 'Nordic Noir', but in spite of many attempts to further a wider distribution of European film and media products, the success stories are still surprisingly few and the cultural encounters on many European screens are still dominated by stories on the American way of life.

\section{Screening the nation - screening Europe}

When talking about European film and television, a highly relevant question is how we actually define a European film or TV drama production. The most simple and obvious definition is that a European film is a film made in one of the countries that we recognize as belonging to Europe in some sense, what one could call a national European film. Such a film is financed only or mostly by national money and made by a creative team coming from that nation. At the other end of the spectrum, there would be films with a high degree of transnational co-financing, creative co-production and with a normally much broader, transnational 
European distribution, what one could call a transnational European film. Such a film might be based on more universal or not so national content, but not necessarily so. Think of the films about Harry Potter or a UK heritage film like Elizabeth: The Golden Age (2007) that in very different ways have a heavy cultural 'Britishness' imbedded in the story. Some data indicate that transnational European films have a much broader audience, but then again, such films also tend to belong to genres that may appeal more widely to a global audience. One can also find many cases where smaller national films actually find a quite significant European audience outside their national territory. This was for instance the case with the German film Das Leben der Anderen/The Lives of Others (2006), and it is similarly the case with some films belonging to the European art cinema tradition, films for instance by Danish Lars von Trier, British Mike Leigh and the Belgian film directors Jean-Pierre and Luc Dardenne.

Looking at the numbers for films produced in the year 2010 with a release in other European countries (from the Lumiere database), the spread in European film's ability to reach a broader transnational audience is striking. Not surprisingly, the bestselling titles are US films, but several of these are US/UK co-productions. Harry Potter and the Deathly Hallows tops the list with 33,700 million admissions across Europe. At the very bottom we find the French film Imogène McCarthery with 582,729 admissions, almost all of them in France. In between those two extremes we find some European co-productions with some transnational European audience figures. The French/Belgian co-production Rien à déclarer/Nothing to Declare, for instance, was seen by 9.8 million Europeans, mostly in France, but also by 1 million people in Belgium and half a million in Germany, while it had smaller numbers when released in five other countries. Roman Polanski's French/German/British political thriller The Ghost Writer was seen by 4.8 million Europeans and is an example of a European co-production that attracted audiences in all EU countries. It is also possible to find examples of national European films with a quite broad European distribution, for instance the French historical drama Des hommes et des dieux/Of Gods and Men by Xavier Beauvois, which has been shown in 19 European countries - albeit with quite modest viewing figures in some - and the film reached all together 4.4 million admissions in Europe (with 3.3 million of these in France).

While discussions of European film tend to only focus on the cinema market, it is important to stress that cinema admissions do not show the whole picture, since Europeans are not only watching films in the cinema; television is in fact a much stronger factor in the shaping of a transnational, European audiovisual space, and to the TV screen one 


\section{Ib Bondebjerg and Eva Novrup Redvall}

can add DVD (which is now a declining market) and the growing online market. However, the patterns of what is available for audiences on the Europeans cinema screens indicate a structural problem that will probably not be changed completely in the new digital media culture. Trends with a long history tend to be reproduced even though new technology creates new possibilities. The limited audiovisual European presence on all types of European screens indicate that we are much more national and American in our cinema and television lives than we are European, but this does not in any way contradict the fact that an increased Europeanization and globalization of our social and cultural imaginaries is taking place. The fact that $43 \%$ of all Europeans consider themselves both national and European, while 56\% sometimes feel European, is an indication of that. The slow development of a European cultural sphere and of a feeling of being a European is, as Fligstein points out, a sign of a new Europe that is still young and where the interconnectedness and the transnational communication patterns are still very much in the making. Unless the EU breaks down as a construction, we are likely to identify more and more with some kind of European identity, next to the national one in which most people are still clearly most at home.

\section{Negotiating and translating cultures}

Danish TV drama is an interesting case in terms of trying to understand how some national productions suddenly find a way to foreign screens and how certain European audiences take an interest in subtitled content from another country (Redvall 2013). Until recently, the Danish production culture has been marked by the belief that national television series - produced as part of a public service television culture targeted specifically at Danish audiences - would not really be understood and appreciated by people in other parts of the world, including Europe. This feeling of living in a bounded, national culture with a small language that nobody else can understand is not just a Danish phenomenon, but widespread in many European nations. The concept of national culture and national identity is often linked to a feeling of living in a unique and home-grown culture, but as analysed in the chapter by Bondebjerg and Redvall in this book the recent international success of Danish TV drama and film shows how productions made for this specific home market can have a much wider appeal than originally expected. Not the least if the stories based on national culture, society and history draw on professional and generic standards and norms that are internationally recognized as having a more universal appeal. 
With his cultural proximity theory, Straubhaar argues that we choose cultural products based on a sense of cultural closeness $(1991,1997,2000)$. However, given the strong presence and acceptance of US/UK products all over Europe, the theory must be modified, to a theory which is not just about proximity, but also about what we grow accustomed to. We can have multiple forms of proximity. All data in Europe point to a strong proximity between national products and the majority of nationals in that culture, but also to a strong preference for American culture. American products have managed to translate into global national cultures, to such a degree that these products are completely integrated into our everyday life and culture. To a certain degree, it is the same for many UK productions. UK is a major producer and distributor, often with a US partner, of both television and film at the European continent. Audiences across Europe have therefore also developed a certain proximity with the UK type of product, be it the James Bond films or the heritage tradition. In contrast, this is not the case for other big cultural producers in Europe, such as Germany and France. Given the size of the German and French home markets and the number of films and television dramas produced there, one would expect a much stronger German or French presence in Europe than is actually the case.

But what happens when single or massive and permanent transnational and mediated encounters happen through film and television? Based on the small case study in Bondebjerg and Redvall's chapter in this book, and also indicated by broader reception studies (Liebes and Katz 1993; Barker and Mathijs 2008) there seems to be a combination of a fascination with the foreign elements and different forms of negotiation and translation between the producing and receiving culture. The Danish political drama series Borgen (2010-2013) or the crime series Forbrydelsen/The Killing (2007-2012) were accepted in the UK and other European nations despite the subtitles and was somehow perceived as variations of formulas already known and used both nationally and by US product. Yet the interest in the series seemed to be based on a rather strong and dynamic negotiation process with an interesting duality: on the one hand, the encounter with the series led to an interest in interpreting their 'Danishness', an interest in the cultural specificity and otherness which was fascinating; on the other hand, this cultural negotiation also included a kind of demarcation of the receiving culture's own nature or identity. The latter, in numerous articles and blogs, led to comparisons between what English series of a similar kind could or could not do, and to wider discussions of what aspects of the national culture or the forms and norms of everyday life presented in the series 
that were different from the Danish. Similar to what is the case with American film and television in Europe, global distribution is not a one-way street. It is not just about economic dominance or exporting certain views of the world, but a complex process of constantly reading and negotiating the other culture in the context of one's own.

The history of the reception of American cultural products in Europe can in many ways be seen as a model of what is now happening in European cultural integration on a much smaller scale, but could unfold much stronger if there were more exchange of film and television across the European borders in the future. As many studies have shown, European audiences have always both loved and hated American culture (e.g. Webster 1988; Kroes 1996; Pells 1997), and in many ways one can trace a similar love and hate for European culture. Intellectuals have often regarded American culture as an invasive, commercial mass culture and a threat to what has been perceived as a more authentic and valuable European culture. At the same time, European film and television has always looked to America for inspiration, American productions have learned from and imported talents from Europe and collaboration and co-production between US and UK and also other European nations have been very important (Hilmes 2012; Weissmann 2012). Jeanette Steemers's interesting study of British television in a global perspective, Selling Television (2004), clearly demonstrated that European buyers of television for European distribution tend to see products from other European countries as more strange and foreign than American products.

The problem with European distribution of film and television seems to rest on a kind of cultural Catch-22: we are not used to seeing European products and thus we assume that they are strange and different; because of this assumption buyers and distributors do not actively seek European products, and a dynamic that could break this pattern is not set in motion. Consequently, a broader European encounter on our screens is not taking place. This is the spell that European film and media policy has been trying to break since the 1980s, so far with limited power and limited effect. The way in which some European content, such as the current Danish TV drama series, is now somewhat surprisingly finding audiences outside of the domestic market, does indicate that changes are starting to happen and that what television scholar Elke Weissmann has described as potential 'counter-flows' to the dominating US fare might be gaining ground (2012: 191). What has in fact happened in the wake of the popular Danish or Nordic Noir series is that broadcasters across Europe are now starting to ask 
for more European TV drama, and the series have thus possibly paved the way for a broader European success. A new tendency towards more transnational and pan-European forms of co-productions that include a transnational cast, story and language format is also interesting in this context. Crime series like the trans-media experiment The Spiral (2012), Crossing Lines (2013- ) and The Team (2015) have tried to create a natural framework for transnational European stories because the series deal with transnational crime. The series involve co-production and a cast from several European countries, and the characters speak both their own language and English as a common language. Series like these point to a new development where nationally produced series and films (often with European co-financing) try to target a broader European market from the outset. This could open far greater possibilities for European audiences to meet a wider variety of stories on being European and different variations of European everyday life on the big and the small as well as the many alternative digital screens in the years to come.

\section{Outline of the book}

European Cinema and Television: Cultural Policy and Everyday Life offers a range of different perspectives on the complex issues of European cultural integration and the role of film and television in this process. In analysing these issues, the contributors draw on humanities theories, methods and forms of analysis and social science approaches. The book is divided into four main sections each addressing central aspects of European film and television's role in the discussion of a broader European culture.

In Part I, Culture, Identity and Everyday Life, the focus is on theories and examples of how national, regional and transnational dimensions interact in our everyday life and the way in which we encounter film and media. The chapters address how media content can influence our feeling of ourselves and of others as well as our memory. Moreover, the chapters deal with political dimensions of European culture and how specific policies or developments may influence the minds and everyday life of ordinary Europeans.

Monica Sassatelli's chapter Narratives of European Identity addresses the development and current interpretations of narratives of European identity, with particular reference to institutional narratives - those produced and supported by the institutions that call themselves European such as for instance the COE and the EU. She argues that contemporary Europe is a good example of both the possibilities and the dangers of 
narratives of identity, as well as a useful term of comparison for other identity narratives, in particular national ones. An important dimension of analysis concerns how institutional European narratives are translated into practice and performed by recipients of the policies. Sassatelli uses the EU's European City/Capital of Culture programme as her main case.

Michael Meyen's chapter Film and European Identity is a German-based case study of the role of film and TV drama in the everyday life of 'ordinary' citizens and of the extent to which the question of European identity is linked to this relationship. The chapter outlines theoretical and methodological perspectives on this topic and also draws on empirical material from focus groups and personal interviews with young Germans. The data show that media are not the most important factor in the shaping of a collective identity, but on the other hand European films do shape the perceptions of other European countries.

Tim Edensor's chapter Sensing National Spaces: Representing the Mundane in English Film and Television argues that the national continues to hold a powerful gravitational pull over the constitution of contemporary identities even though dynamic processes of globalization also exist. The chapter analyses how national identity inheres in the everyday worlds of mundane space. In the UK, this everyday world is increasingly colonized by global and European elements, yet it is usually quickly absorbed into local and national settings.

In the second part of the book, Film and Media Policy: Between the National and the Transnational, the focus shifts to transnational film and media policies in Europe. The two chapters in this part deal with the building of a European film support policy and an audiovisual space in a broader sense. The chapters explore the results of these developments, drawing on concrete examples of co-production and of the new development towards a transnational digital film and media culture.

Carmina Crusafon's chapter The European Audiovisual Space: How European Media Policy Has Set the Pace in its Development looks at the European audiovisual space as one of the core concepts in the European media policy. During the last two decades, European institutions have undertaken different measures and initiatives to encourage the circulation of audiovisual works within the European space. This area still has not yet reached its full development, and responds more to a political conception rather than an industrial and social reality. Given these difficulties, the European audiovisual policy has looked for two allies: digitization and openness to the global market. Though these two elements are contributing to its development, the European audiovisual 
space is now facing new challenges due to future EU policy guidelines (EU 2020 Horizon and Creative Europe).

Sophie De Vinck and Caroline Pauwels' chapter Beyond Borders and Into the Digital Era: Future-proofing European-level Film Support Schemes focuses on the film sector in Europe in the midst of a digital transition and on how this will contribute to how future borders in this sector will be shaped. They take a closer look at the key challenges that the sector is facing and how EU programmes like MEDIA and Eurimages are responding to them. While the future European film landscape will not be without borders, a number of indicators do point towards the possibility to move increasingly beyond traditional sector policy-making and geographical borders. In this regard, European-level solutions could become increasingly important in order to address the film industry's challenges in a digitized environment.

The last two sections of the book move closer to the analysis of national and European tendencies in film and television genres in a broader social and cultural perspective. The third section, National Cinemas - European Cinemas, investigates how cinemas with a different national background address the European challenges when trying to reach for a transnational audience and how transformations of European culture such as East-West differences or more multicultural and cosmopolitan challenges are reflected in European cinema.

Andrew Higson's chapter British Cinema, Europe and the Global Reach for Audiences analyses the global reach for audiences of the UK film business, and the way in which UK-based filmmakers attempt to exploit their products in European markets. Which 'British' films prove most exportable, most translatable and therefore most successful in European markets? What sort of 'British' films secure European distribution? The article looks at three different types of films: (1) large-scale UK/US co-productions, (2) films with European content and (3) art cinema films. The article mostly explores the second category and the way in which the content, promotion and reception of such films often depend upon reproducing national stereotypes and national economies in order to achieve a presence in Europe.

Ewa Mazierska's chapter The East Meets the West in Contemporary Eastern European Films analyses films of renowned Eastern European directors from three countries (Poland, Hungary and Estonia) in a regional, cultural perspective. Films by Jerzy Skolimowski, Béla Tarr, Ágnes Hranitzky and Veiko Ounpuu represent international co-productions with significant visibility in the international festival circuit, and they are seen as offering a new form of portrayal of both the East and the West. 
The chapter argues that their representation of the West has much in common with the East represented in these directors' earlier films: it is a bare and cruel land, where survival counts as a success.

Leif Ove Larsen's chapter New Voices, New Stories: Migrant Cinema and Television in Norway examines the role of migration and transnational mobility in contemporary Europe. What is generally labelled multicultural or transnational cinema has not only challenged traditional conceptions of national cinema, but also questioned national schemes of production support. The chapter takes the Norwegian context as a point of departure when analysing the aesthetics and politics of multicultural cinema, while asking how these new tendencies challenge our understanding of national cinema and established patterns of storytelling.

In the last part of the book, National Television - European Television, case studies of Italian, Danish and Irish TV drama point to recent and more transnational dimensions of production and distribution in a European perspective. The chapters analyse institutional developments and changes as well as concrete examples of transnational reception and the role of television in everyday life in relation to the negotiation of national and transnational cultures and identities.

Milly Buonanno's chapter Italian TV Drama: The Multiple Forms of European Influence presents the history of Italian TV drama in relation to both a national culture and history and in relation to the influence from non-national media cultures. The chapter criticizes the tendency to focus too much only on the 'American other', while overlooking the presence and influence of the 'European neighbour' in Italian TV drama. The chapter analyses imports, co-productions, format adaptations and other forms of transnational influences on Italian TV drama.

Ib Bondebjerg and Eva N. Redvall's chapter Breaking Borders: The International Success of Danish Television Drama investigates the background for the Danish public service broadcaster DR's international success since 2002, when the crime drama Rejseholdet/Unit One (2000-2003) won for DR Fiction the first of a series of five Emmy Awards, starting a wave of international distribution. Using Forbrydelsen/The Killing (20072012) as an example, the chapter looks at the production framework of the in-house production unit DR Fiction. The chapter raises questions of the universal and nationally specific dimensions of culture, the relation between national audiences and everyday life and of how this relation is translated to other European cultures, while addressing audience patterns and the reception of the series in especially Denmark and UK.

Finally, Diog O'Connell's chapter Small Nation/Big Neighbours: Co-producing Stories in a European Context explores co-production and 
Irish TV drama in a national and European context, focusing particularly on the public service broadcaster and drama productions since 2000. The last economic recession in Ireland in the 1980s brought with it a policy of co-production and TV drama, which appeared to phase out with economic growth. Co-production became the norm for film production since the 1990s but less so with TV drama. The chapter compares the role of co-production in developing screen narratives and reflects on the current production environment for TV drama in Ireland.

\section{References}

Anderson, B. 1983/1991. Imagined Communities: Reflections on the Origin and Spread of Nationalism. London: Verso.

Appadurai, A. 1996. Modernity at Large: Cultural Dimensions of Globalization. Minneapolis: University of Minnesota Press.

Barker, M. and E. Mathijs (eds). 2008. Watching the Lord of the Rings: Tolkien's World Audience. New York: Peter Lang.

Billig, M. 1995. Banal Nationalism. London: Routledge.

Bondebjerg, I. and E. N. Redvall. 2011. A Small Region in a Global World: Patterns in Scandinavian Film and Media Culture. Copenhagen: European Think Tank on Film and Film Policy, CEMES Working Papers, no. 1.

Council of Europe. 1954. The European Cultural Convention. European Treaty Series. No. 18.

European Commission. 1984. Television without Frontiers. Brussels: Directive 89/552/EEC of October 1989.

-1998. Audiovisual Policy of the European Union. Brussels: Publication Office of the European Union.

- 2010. Unlocking the Potential of Cultural and Creative Industries. Green Paper. Brussels: 27.4.2010. COM(2010) 183 Final.

. 2014a. A Profile of Current and Future Audience. Luxembourg: Publication Office of the European Union.

- 2014b. A Profile of Current and Future Audience. Executive Summary. Luxembourg: Publication Office of the European Union.

Fligstein, N. 2008. Euroclash: The EU, European Identity and the Future of Europe. Oxford: Oxford University Press.

Herman, E. S. and R. W. McChesney. 1997. The Global Media: The New Missionaries of Corporate Capitalism. London/Washington: Cassell.

Hilmes, M. 2012. Network Nations: A Transnational History of British and American Broadcasting. New York and London: Routledge.

Kroes, R. 1996. If You've Seen One, You've Seen the Mall: Europeans and American Mass Culture. Urbana and Chicago: University of Illinois Press.

Liebes, T. and E. Katz. 1993. The Export of Meaning: Cross Cultural Readings of Dallas. London: Polity Press.

Miller, T. and N. Govil, J. McMurrin, R. Maxwell, T. Wang (eds). 2005. Global Hollywood 2. London: BFI/Palgrave Macmillan.

Papathanassopoulos, S. and R. M. Negrine. 2011. European Media. London: Polity. 


\section{Ib Bondebjerg and Eva Novrup Redvall}

Pells, R. 1997. Not Like Us: How Europeans Have Loved, Hated and Transformed American Culture since WWII. New York: Basic Books.

Redvall, E. N. 2013. Writing and Producing Television Drama in Denmark: From The Kingdom to The Killing. Basingstoke: Palgrave Macmillan.

Sassatelli, M. 2009. Becoming Europeans: Cultural Identity and Cultural Politics. Basingstoke: Palgrave Macmillan.

Steemers, J. 2004. Selling Television: British Television in the Global Market Place. London: BFI.

Straubhaar, J. 1991. 'Beyond Media Imperialism: Asymmetrical Interdependence and Cultural Proximity'. Critical Studies in Mass Communication, 8:1, pp. 39-59. 1997. 'Distinguishing the Global, Regional and National Levels of World Television'. In A. Sreberny-Mohammadi, D. Winseck, J. McKenna and O. BoydBarrett (eds), Media in Global Context. London: Arnold, pp. 284-298.

2. 2000. 'Culture, Language and Social Class in the Globalization of Television'. In G. Wang, J. Servaes and A. Goonasekera (eds), The New Communication Landscape. London: Routledge, pp. 199-224.

Treaty of Rome. 1957. Treaty establishing the European Economic Community, 25 March 1957. Retrieved from http://www.epg.acp.int/fileadmin/user_upload/ rometreaty2.pdf. Accessed 29 November 2014.

Webster, D. 1988. Looka*Yonder! The Imaginary America of Populist Culture. London: Comedia/Routledge.

Weissmann, E. 2012. Transnational Television Drama: Special Relations and Mutual Influence Between the US and UK. Basingstoke: Palgrave Macmillan. 


\section{Index}

'71 (2014) 128

A Dangerous Method (2011) 142-3

A Field in England (2013) 128

A Londoni férfi/The Man From

London 162-3

A torinói ló/The Turin Horse

(2011) 162-3

Abrams, J. R. 45

Adaptation 20,142-3, 179, 197-8, 201-6, 209-10, 245, 247

Aeneid (1971) 201

Agamben, G. 152, 157, 159, 166

Agger, G. 228-9

Akin, F. 170

Alarm für Cobra 11 (1996-) 208, 210

Alfred Hitchcock Presents

(1955-1965) 206

Ali Reza and the Rezas (2009-2010)

180-1, 183, 185

Allen, W. 142, 148

Amélie (2001) 55

Americanization 75, 196, 207

Amongst Women (1998) 245-6

Anderson, C. 108, 128

Angel's Share, The (2012) 142

Andersson, B. 6, 60, 64, 218

Appadurai, A. 11-12, 73

Arnold, A. 68

Arrow Films 225

Arthur Christmas (2011) 141

Audio-visual policy (European

Union) 4, 18, 26, 39, 81-2, 85, $87,91-6,98-9,116,138,215$, 240

Auf der anderen Seite/The Edge of Heaven (2007) 170

Bachelors Walk (2001-3) 249-50, 254

Badiou, A. 152

BAFTA/awards 220, 231

Bakøy, E. 170, 172

Balibar, E. 27
Baransky, Z. G. 207

Barbato, J. C. 103-5

Barker, J. 67

Barker, M. 15, 230

Barroso, M. 97

Bashir, L. 175

Bawke (2005) 174

Beautiful Country, The (2004) 172-3

Beauvois, X. 13

Beck (1997-2010) 224, 231

Beinek, J. 153

Bell, J. 144

Belle ét Sebastian (1965-70) 207

Belphégor ou le fantome du Louvre (1965) 206

Bend it like Beckham (2002) 170

Berghahn, D. 171-2, 184

Bergson, H. 177

Best Exotic Marigold Hotel, The (2011) 142

Beurier, P. 103-4

Bible Project (1993-2002) 202

Billig, M. 6, 59-62

Blodsbånd/Mirush (2007) 172

Blokker, P. 151

Boat That Rocked, The (2009) 142

Boland, J. 251

Bondebjerg, I. 187, 216, 221-2, 227

Bonicelli, V. 201

Borgen (2010-2013) 15, 58, 223, 229 , 231-4, 236

Borowczyk, W. 155

Bourdieu, P. 44, 47, 64

Boy in the Striped Pyjamas, The (2008) 142

Braccialeti rossi/The Red Band Society (2014) 206

Bradley, R. 252

Braidotti, R. 27

Braquo (2005-) 208

Braveheart (1995) 61

Breaking Bad (2008-13) 221, 249, 251 
Bren, P. 154-5

Brennan, E. 242

Brinkman, S. 51

British Film Institute (BFI) 130-2, 135-6, 140

Britishness $11,13,73,128,211,219$, 233

Brodén, D. 224

Broen/The Bridge (2011-) 229

Brostrøm, M. 227

Bruter, M. 48

Buonnano, M. 196, 200, 202-3, 207, 217,236

Burgess, A. 201

Byard, O. 218

Cagney \& Lacey (1981-88) 229

Carolan, S. 252

Carter, S. 68

Caughie, J. 240, 242, 249, 255

Cederman, L. E. 48

Celtic Tiger (boom, years) 249-51, 256

Cesaronis, The (2006) 204-5

Charlie and the Chocolat Factory (2005) 89

Christensen, M. 171

Cialdini, R. B. 44

Cién/Shadow (1956) 153

Cinema/Film

British/UK 19, 56, 59, 67, 69-71, 127-34, 136-41, 143-5, 147-8, 157-60, 162, 170, 189, 201

Belgian 13, 143-6

Danish/Scandinavian 13, 138, 144, 170-2, 187, 216

European $11,17,19,45,50,84$, $127,139,152,157,170$,

Hollywood/American 5, 6, 16, $20,51,54,59,103,66,75,103$ 106-10, 116-17, 127, 129-35

Migrant cinema (see chapter 8)

Cinema/Film genres

Action/Adventure 139, 141, 173, 182, 184

Animation 141

Biopics 141, 202

Comedy 139, 141, 167, 173-84, 204-5, 249
Contemporary drama $127-8,142$, 151

Crime/thriller 83, 141, 143, 173, 175

Family films $141-2,147,171$

Historical/period/heritage 13, 15, $61,98,133,141-3,195,202$

Middlebrow drama 133, 141-2, 147

Clinic, The (2003-2007) 251

Constant Gardener, The (2005) 142-3

Co-production $4,10,12-13,17-19$, 20-1, 74, 89, 104, 106, 111-14, $127,130-40,144,152,199-02$, 208-10, 214, 217, 220-4, 227, 235

Collins, R. 215

Cooper, F. 25

Copple Smith, E. 68,202

Coronation Street (1960-) 68, 70-2

Corp \& Anam (2011) 251

Couldry, N. 195

Council of Europe (COE) 3, 26, 88, $103,131-2,138,214-15$

Creative Europe (see EU programs)

Creswell, J. N. 51

Cronenberg, D. 142, 148

Crossing Lines (2013-) 17

Crouch, D. 63

Crusafon, C. $18,93,102,105,116$, 139,215

Cultural (concepts) diversity $1,5,39,81,91-4,97$, 99, 105, 189

encounters $1,7-8,10,12,147$, $177,183,217$

identity $7,8,25,28-9,4056,86$, $143,145-6,170,172,180,183$, 203, 233

policy $1,3-5,10,17,26,36,43$, $186-7,214,236$

Curran, J. 195

Czarniawski, B. 30

Danishness 15, 233

Dardenne, J.-P. \& L. 13

Das Leben der Anderen/The Lives of Others (2006) 13

De Mauro, T. 197 
De Vinck, S. $11,19,88,103-7$, 109-13, 139

Dekalog (1988) 155

Delany, S. 250

Derrick (1979-2000) 208

Derrida, J. 27

Des hommes et des dieux/Of Gods and Men 13

Dewandre, N. 27

Doctor Who (2005-) 208

DR dogmas 223, 227, 235

Dolmen (2005) 204

Downton Abbey (2010-) 208

Dr. Zhivago (2011) 222

Durham Peters, J. 201

Durovicova, N. 171

East is East (1999) 170

Eastenders (1985-) 68, 72

Eastern Promises (2007) 142

Easy Virtue (2008) 141

Edensor, T. 11, 59, 61-3

Eder, K. 28-9, 40

Edge of Tomorrow (2014) 61

Edgerton, G. 201

Eliashberg, J.A. $107-8$

Elizabeth: The Golden Age (2007) 13, 141,143

Elsaesser, T. 170

Emmy (Award) 20, 201, 217, 220, 223, 226

Engrenages/Spiral (Canal Plus 2005-) 201

Erdogan, N. 171

Eriksson, E. H. 47

Essential Killing (2010) 151, 157-60

EU programs

Creative Europe $4-5,19,82,87$, 97-8, 102, 105, 115-16, 118, 138, 215

Media 19, 35, 85-8, 90-5, 97-9, 102-4, 106, 110-17, 133, 135, $138,145,215,239,243-4$

EURIMAGES $4,19,88,102-4,106$, 111-12, 114-19, 131-2, 135-6, 138, 140, 215, 239, 243

European City/Capital of Culture 34-6, 40-1

Europa (1991) 51
European audio-visual space 13,18 , 81-6, 91, 98, 102, 215

European Broadcasting Union (EBU) 83, 214, 220, 244, 256

European Commission $4-5,9,32-5$, $40,81,86,91,93,98,106,110$, $113-15,118,129,133-5,138$, 215,235

European Forum on Cultural Industries 5

European integration $10,25-6,28-9$, $38,41,85,98$

Europeanization $7,10-11,14,37-8$, $72,83,86,196,211$

Europeanness 39-40, 105, 209-11

Eurovision Song Contest 9

Everyday life 1, 2, 5-8, 15, 17-18, $20,43,49,55,58-9,62,64$, 67-71, 73, 81, 128-9, 155, 169, $180,182,189,204,230$

Farago, J. 231

Fares, J. 170

Farrell, C. 144

Father and Son (2008) 248

Film Socialisme (2010) 152

Finney, A. 219

Fish tank (2009) 68-70, 128

Fisica o quimica/Physical or Chemical (2008-11) 208

Fliegstein, N. 6, 8, 10, 14

Flushed Away (2006) 141

Footballers' Wives (2002-2006) 204

Før snøen/Before Snowfall (2013) 175-6, 184-5

Forbrydelsen/The Killing (20072012) $15,20,58,216-18,223$, 226-34, 236

Forgacs, D. 198

Forsyte Saga, The (1967) 206

Freud, S. 143, 163

Frost, V. 216

Frye, N. 176, 183

Frykman, J. 64

Gallo, V. 159

Gardiner, N. 133-5

Gauntlett, D. 44

Gegen die Wand/Head-On (2004) 170 
Gerbner, G. $\quad 44,55$

Ghost Writer, The 13

Gibbons, L. 241

Giddens, A. 45-9, 63

Giles, H. 45

Gillen, A. 251-2

Gleeson, B. 144

Globalization $1,7,11,14,18,30$, $47,65,72,127,147$

Godard, J.-L. 152

Golden Globe 201

Gollwitzer, P. M. 44

Goodridge, M. 136

Gottschall, J. 221

Grant, P. 217

Grasso, A. 207

Grodal, T. 221

Gross, L. 44, 55

Gråbøl, S. 218

Gubbins, M. 109

Habermas, J. 27

Hall, S. 44

Haneke, M. 152

Happy-Go-Lucky (2008) 142

Harcourt, A. 83, 104, 106

Hardt, M. 152, 163

Harrison, B. 251-2

Harry Potter films 128, 139-42, 148

Harry Potter and the Deathly

Hallows 13, 89

Harry Potter and the Goblets of

Fire 139

Harvey, D. 152, 154, 156, 163, 165-6

Henriksson, K. 225

Heritage (concept, policy) 3-4, 7, 12, $28,37,61,103,195,198,214$, 233, 240, 245

Herman, E. S. 11

Herold, A. 103-4

Hesmondhalgh, D. 82

Higson, A. $19,61,128,136-7,188$, 224

Hilmes, M. 16

Hjort, M. 136, 140-2, 170-3, 210, 226

Hogan, M. 231

Holland, A. 154

Holocaust (1978) 207
Holst, M. 172

Homeland (2011-) 251

Hooper, T. 133

Hospital Central (2000-2012) 204

Hranitzky, Á. 19

Hrebejk, J. 167

HULU 253

Huntington, S. 157

Hussain, K. 173

Idriss-Miller, C. 62

Imagination/Imagened community $6,11,12,31,60$, $64,67,199,218,230,242$

Imogène McCarthery (2010) 13

Import-eksport (2005) 173

In Bruges (2008) 143-7

Intouchables (2011) 139

Irish Film Board 244, 246, 248

Iron Lady, The (2011) 142

Izzat (2005) 173, 184-5

Jack Taylor (2010-13) 251

Jakubowska, W. 153

Jalla!Jalla! (2000) 170

James Bond films 15, 139-41, 148

James Bond - Casino Royal (1989) 141

James Bond - Skyfall (2012) 139

James Bond - Thunderball (1965) 61

James Bond - Quantum Solace (2008) 89

Jandura, O. 44

Jane Eyre (2011) 128

Janion, M. 158

Jeffres, L. W. 44

Johnny English (2003) 128, 141

Jones, H. 129, 136-7, 139, 141, 147-8

Joyce, J. 250

Jung, C. 143

Just, N. 82

Kachyna, K. 153

Kantner, C. 27

Karambolage (2004) 74

Kárhozat/Damnation (1988) 161-2

Katz, E. 15, 230

Kawalerowicz, J. 153

Keaton, B. 177

Keynes, J. M. 154 
Kideckel, D. 156

Kieslowski, K. 155-6, 161

King's Speech, The (2010) 133-5, 137, $139,141-2$

Kingdom of Heaven (2005) 141, 143

Kingsley, P. 232

Klapisch, C. 50

Klobah, L. C. 170

Kobieta samotna/A Woman Alone (1981) 154

Kommisar Rex (1994-2004) 208

Kopps (2003) 170

Kovacs, A. 161

Král Sumavaru/The King of Sumava (1959) 153, 160

Kráska v nesnázích/Beauty in trouble (2006) 167

Kroes, N. 96

Kroes, R. 16

Krutnik, F. 176-7

Kümpel, A. 49-50

Kutsumata külalised/Uninvited Guests (1959)

Kvale, S. 51

L'auberge Espagnol/ The Spanish Apartment (2002) 50

La Piovra/The Octopus (1984-2001) 202

La vita di Leonardo da Vinci/The Life of Leonardo da Vinci (1971) 201

Ladegaard, J. 157

Lakmari, N-E. 173

Larsen, L. O. 20

Lassgård, R. 225

Last King of Scotland, The (2006) 142

Le locataire/The Tenant (1976) 155, 163

Le Regard (2005) 173-4, 184-5

Left Bank Pictures 225

Leigh, M. 13, 128, 142

Lekachman, R. 154

Lenoble, J. 27

Les Miserables (2012) 128

Lewis (2007-) 231

Liebes, T. 15, 230

Life ion Mars (2006-07) 208

Lippard, L. 63
Lisbon Treaty/Agenda 34, 106

Littoz-Monnet, A. 105

Livvagterne/The protectors

(2008-10) 223

Loach, K. 128, 136, 142, 148

Löfgren, O. 64

Looking for Eric (2009) 142

Lord of the Rings, The 230

Los Serrano (2003-08) 205

Love/Hate (2010-14) 249-54

Lowenthal, D. 62

Lumley, R. 207

Luther (2010-13) 208

Maastricht Treaty (1993) 4, 28, 33, $35,105,214$

Mad Men (2008-) 221

Malik, S. 170, 189

Mankell, H. 225

Marshall, C. 49

Massey, D. 63

Match Point (2005) 142

Mathijs, E. 15, 230

Mazdon, L. 209

Mazierska, E. 19, 155

McCarthy, N. 247

McChesney, R. W. 11

McCormack, D. 68

McDonagh, M. 144, 146

McDonald, M. 82-3

McElroy, A. 67

McGahern, J. 245

McGaughren, S. 254

McGinnity, A. 252

McMurria, J. 201-2

McQuail, D. 208

Meadow, S. 70

MEDIA (see EU programs)

Mediatization/mediated 1, 7, 9-12, $15,47,58-9,68,70-3,75$

Medrano, J. D. 38, 41

Meyen, M. 18, 44, 49

Miller, J. S. 204

Miller, T. 6

Mirren, H. 229

Mis/Teddy Bear (1978) 154

Misfits (2009-) 208

Mitchell, R. 136

Moland, H. P. 172 
Moonlighting (1982) 155

Moores, S. 72-3

Moran, A. 203

Morley, D. 44, 66

Morris, N. 195

Mosco, V. 82

Mr. Bean's Holiday (2007) 141, 143

Murphy, C. 252

Mustafa, H. 175, 187

My Beautiful Italian Family

(2014) 202

NacConghail, M. 247

Nadermann, P. 227

Naficy, H. 171

Neale, S. $\quad 176-7$

Negri, A. 152,163

Negrine, R. 7, 83, 86

Neighbours (1985) 203

Neiiendam, J. 136

Nelson, J. 157

Nelson, R. 221

Netflix 253, 110, 116

Newman-Bandais, S. 119

Newman, K. 171

Nikolaj og Julie/Nikolaj and Julie (2002-2003) 223

Nikoltchev, S. 109

Nordic Film and TV Fund 220

Nordic noir 218, 224-5

Nordvision/Fund 220, 227, 235

Norwegian Film Institute 187

Notes on a Scandal (2006) 142

Notting Hill (1999) 128

Nussbaum, M. 31

Odissey (1968) 200

Opowiesc Atlantycka/Atlantic Story (1955) 153

Other Boleyn Girl, The (2008) 141

Panelkapcsolat/The Prefab People (1982) 161

Papathanassopoulos, S. 7, 83, 86

Parallel Films 246

Park, M.-J. 195

Pauwels, C. 11, 19, 82-3, 103-4, 139,215
Pells, R. 16

Perennial themes of nation 226

Persuaders, The (1971-72) 206

Perry Mason (1957-66) 206

Pham, A. 227

Pierwsza milosc/First Love (1974) 161

Pieterse, J. 73

Pirates! Band of Misfits (2012) 141

Ploughman, S. 252

Plunkett, J. 245

Plunkett, M. 250

Polanski, R. 13, 155, 163

Polanyi, K. 154

Polseres vermelles (2011-) 206

Price, The (1985) 247

Pride and Prejudice (2005) 128, 141

Prime Suspect (1991-2006) 229

Profilage (2009-) 208

Public service $4,14,20-1,83-4$, $103,188,197-8,200,214,216$, 219-20, 222-3, 235, 240-1, 243-4, 247-8, 250, 253, 255

Puppis, M. 82

Puttnam, D. 129, 214

Queen, The (2006) 142

Ranciere, J. 155

Realism 180, 186, 225, 228, 247, 249,253

Reception (film and television) 2, 15-16, 19-20, 85, 143, 170, 184, 209-10, 216, 220, 229-36, 245, 251

Redvall, E. N. $6,12,14-15,20,216$, 221-3, 227

Reich, N. K. 227

Rejseholdet/Unit One (2000-04) 20, 223

Richardson, K. D. 44

Rien à Déclarer/Nothing to Declare (2010) 13

Rixon, P. 196

Rob Roy (1995) 61

Robertson, R. 73

Rødt hjerte/Red Heart (2011) 175, 184-5, 187

Rolfsen, U. I. $173,181,186$

Rossman, G. B. 49 
Saint, The (1962-69) 206

Sam and Sally (1978-80) 207

Sand, G. 217

Sarikakis, K. 82

Sassatelli, M. 5, 17-18, 27-8, 31, 35,40

Sátántangó/Satan Tango (1994) 161-2

Schiller, H. 196

Schlenker, B. R. 44

Schlesinger, P. 82,98

Schönbach, K. 44

Scottish Screen 136

Seagrave, K. 206-7

Seidl, U. 152

Self (concepts of self) 7, 40, 43, 44, $45-52,54,163,189,242$

Self, D. 143

Selznick, B. 201

Sheehan, H. 241, 243-7

Sherlock Holmes (2010-) 208

Shore, C. 27

Showrunner 223

Silj, A. 198

Simonson, P. 201

Single drama 242

Single-Handed (2007-10)

Sjöwall, M. 224-5

Skey, M. 60, 66

Skins (2007-13) 208

Skolimowski, J. 19, 151-2, 155, $157-8,160,163,165-7$

Slumdog Millionaire (2008) 142

Smith, A. 61

Sobchack, V. 67

Spiral, The (2012) 17

Steele, D. 130, 141

Steemers, J. 16, 217, 219-20,

Sternberg, C. 171-2, 184

Stojanova, C. 161

Stok, D. 155

Straubhaar, J. D. 15, 195, 199, 219

Strumpet City (1980) 245

Success is the Best Revenge (1982) 155, 163

Sutcliffe, T. 232

Sveistrup, S. 227

Tajfel, H. 44, 48, 53

Tarr, B. $19,152,161-4$
Taxa (1997-99) 222

Taxi (2012) 181-2, 185-6, 188

Tay, J. 195

Taylor, J. 62

Team, The (2015) 17, 83

Television drama/genres 2, 9, 18, $66,169,208,217,231-2,235-6$, 241, 255

American TV drama 206, 234, 242, 251, 252-3

Biblical drama 201

British/UK TV drama 79, 208, 211 , 219-20, 222, 234, 251-4

Contemporary/Teen/Family/

Political drama 15, 204, 205, 206, 232

Crime drama $15,17,20,221$, 250-1

Danish TV drama (see chapter 10) and $14,16,17,20,231,235-6$

Drama serials $59,203-4,244$

European TV drama 12, 15, 17, 206-11, 216-7,234, 236, 240

French TV (drama) 74, 201, 206-9, 211, 220, 244

German TV (drama) 59, 74, 87, 202, 207-8, 210, 227, 231, 244

Historical/Period/Heritage drama 13,61

Irish TV drama (see chapter 11) and 21

Italian TV drama (see chapter 9) and 12,20

Legal drama 206

Medical/Hospital drama 206, 250-1, 253

Norwegian TV drama 170, 180-3, 186, 188, 225

Realist/kitchen sink drama 87 , 242, 253

Single drama 217

Sitcoms 67, 180-1, 185, 222

Soap opera/soaps $47,59,67-8$, 70-2, 180, 203, 222, 242, 245

Television stations

Antena 2-3 (IT) 206, 208

ARTE (TV Channel) 74, 204, 217

BBC 158, 198, 206, 208-9, 217-18, $225,231,240-1,243-6,249$ 
Television stations - continued

BBC Scotland 72

BBC NI (IRL) 244-6, 249, 252

Canal Plus (FR) 208

Canale 5 (FR) 202, 205

CBS 201, 206-7

Channel 5 (UK) 253

Danish Television (DR) 20, 216, 217

DR Fiction and drama 20, 217, 222-3, 227-8, 232, 235-6

Eurosport 8

ITV (UK) 70, 204, 206, 208, 240-1, 244, 248-9, 253, 255

Mediaset (IT) 200, 205, 207

NBC 206

NRK (NO) 181, 188

ORTF (FR) 206-7

RAI (IT) 200-4, 206-7, 209

RTE 1-2 (IRL) 241, 243-54, 256

RTL (DE) 208

SAT 1 (DE) 208

Telecino (ES) 204-5

TF1 (FR) 204, 208

TG4 (IRL) 241, 248

TV 2 (NO) 180, 188

TV3 (IRL) 241, 248

ZDF (DE) 227

Telecommunication 105,107

Temptation of St. Tony, The (2009) 151, 164-6

Terzis, G. 83

Theiler, T. 103, 105

Thirty Nine Steps, The (1978) 81

This is England (2006) 64, 68, 70

Thorsboe, P. 227

Thorsboe, S. 222

Thorsen, N. 232

Thussu, D. 195

Tinker, Tailor, Soldier, Spy (2011) 128, 141

Titanic (2012) 202

Tomme tønner/Empty Barrels (2009) 175

Topical themes 226

Torchwood (2006-11) 298

Touraine, A. 27

Townsend, N. 128, 136, 140
Transnational $1-2,7,195,203,214-16$, $218,220-1,226,229,234-5$

Traynor, I. 158

Treaty of Rome (1957) 3, 103

Trepte, S. 44

Trevor, W. 245

Trier, L. V. $13,52,152$

Turner, J. C. $\quad 44,48,196$

Turner, G. 195

Twain, M. 195

Tyrannosaur (2011) 128

UK Film Council 134, 144-5

Ulin, J. C. 108

Un long dimanche of financailles/A very long Engagement (2004) 98

Un medico in famiglia/A Doctor in the Family (1998-) 204-5

Un posto al sole/A Place in the Sun (RAI 1996-) 203

Unity in diversity $2-3,27-32,35-39$, $82,215,236$

Valiant (2005) 141

Vanderstraeten, S. 146

Vassiliou, A. 133

Video on demand (VOD) 81, 87, $107-10,112-3,128,138$

Vidocq (1967) 206

Vinck, S. de 88, 103-7, 109-12

Vinterland/Winterland (2007) 174-5, $177-9,183,185$

Virgil 201

Wahlöö, P. 224-5

Waisbord, S. 195

Waits, T. 250

Wajda, A. 154

Wallace and Gromit in The Curse of the Were-rabbit (2005) 141, 148

Wallander (1991-) 225

Wasko, J. 82-3

Webster, D. 16

Weder, F. 45-6

Welfare state/society $26,154,224$, 232-3

Weissmann, E. 16, 236

Westminster Media Forum 131 
White, H. 30, 39

Wicklund, R. A. 44

Wire, The (2002-2008) 249

Williams, R. 63

Wimbledon (2004) 61

Whitemore 242

Wolff, L. 153

Wood, C. 217

Wright, R. 170

Wuthering Heights (2009) 128

Wycherley, D. 250
Yellow Bird 225

Yeltsov, I. 153

Youdice, G. 39

Zaman, H. 174-6

Zizek, S. 152, 163

Zodiague (TF1 2004)

Zulawski, A 155

Ørnen/The Eagle (2004) 226-7

Ounpuu,V. 19, 151, 164 